\title{
Museumspolitik og generalkonferencen 2007
}

\author{
MERETE IPSEN*
}

Med blik på det museumspolitiske var generalkonferencen 2007 væsentlig. Både med sit tema Museerne og Universel Kulturarv og med vedtagelse af den nye strategiske plan. ICOM har som verdensomspændende ngoorganisation vist sig levedygtig i mere end 60 år. Ser man bagud gennem årenes temaer og resolutioner fra generalkonferencerne, har vilje til forandring og nyorientering som hovedregel været på dagsordenen - om end man også kan få øje på, at ICOM har udviklet sig til at være en tung og noget træg organisation. Men åbenheden overfor at tænke nyt og lade sig udfordre af de forandringer, der sker i det omgivende samfund, overskygger heldigvis det tunge i den store organisation, som tæller 22.000 medlemmer fra 145 nationer.

$10 \%$ af medlemmerne deltog i konferencen, som var den talmæssigt største, der er holdt gennem årene.

Generalkonferencerne, som afholdes hvert 3. år, understreger ligheder mellem museumskolleger verden over. Det er ganske beundringsværdigt, at museer af alle slags fra alle dele af verden, store som små, kan mødes og fremme den museumsfaglige samhørighed gennem udveksling af viden og erfaringer. Det kan de, fordi der grundlæggende er så mange fælles træk, og museer, som tilslutter sig ICOM men ellers er nok så forskellige, arbejder ud fra samme grundprincipper for faglig- hed, kollegialitet, etik, offentlig tilgængelighed og ikke-kommercialitet.

Konferencens tema om universel kulturarv gjorde det rimeligt tydeligt, at det universelle i museernes verden er defineret ud fra europæisk materialitet, hvilket også påvirker definitionerne af samlings- og bevaringsstrategier andre steder i verden. Mange steder arbejdes der på, at sætte noget andet i stedet for, immateriel kulturarv f.eks. Flere tværgående seancer i løbet af konferencen satte også fokus på diversitet $\mathrm{i}$ kulturbegrebet og immaterialitetens betydning.

Det store politiske punkt var den strategiske plan 2008-2010, som blev fremlagt og vedtaget af generalforsamlingen. Den afspejler et behov for at matche globaliseringen og sammenknytte de del-programmer, som er vedtaget som pejlemærker for ICOM gennem de seneste år, eksempelvis konventionerne om immateriel kulturarv og om diversitet, de nye etiske regler og ICOMs beredskab til at yde en indsats i krigs- og naturkatastrofeområder.

Den strategiske plan bærer overskriften Vores Globale Vision.

Med afsæt i globalisering og teknologiens hurtige udvikling ser ICOM det som en udfordring at sikre kulturel identitet og fremhæve kulturel mangfoldighed. Det musealt konserverende, som ligger i kulturarvsbegrebet, og det dynamisk udviklende, som ligger i spæn- 
dingen mellem fastholdelse af kulturel identitet og fremhævelse af kulturel mangfoldighed, er simpelthen sat på dagsordenen for udviklingen i ICOMs strategiske plan.

Såvel ICOMs eksterne relationer til omverdenen som den interne organisering har ændret sig markant gennem de senere år. Globaliseringen betyder øget kommunikation og samarbejde over lange afstande. Med globaliseringens tættere relationer vokser behovet ind i organisation for, at medlemmerne fra de forskellige verdensdele stilles mere lige. Der skal arbejdes for, at mulighederne for at deltage $\mathrm{i}$ og præge ICOM-samarbejdet bliver mere lige, uanset geografi og faglighed, køn og alder. Diversitet skal tænkes ind $\mathrm{i}$ alle møder.

Eksternt skal ICOM være proaktiv og arbejde for at promovere ikke bare museerne men kulturarv bredt forstået. I strategien understreges, at ICOM skal arbejde for, at betydningen af kulturarv slår igennem alle steder på jorden og stadfæstes i offentligheden.

Det understreges, at ICOM er et netværk. ICOM er ikke sekretariatet eller præsidenten eller Executive Council - men netværket er de aktive museumsprofessionelle medlemmer fra hele verden. ICOM-netværket arbejder 'for en verden, hvor betydningen af natur-og kulturarv er universelt anerkendt.' Naturarv er her placeret på niveau med kulturarv. Natur forstås som en del af kulturen, og sammenhængende hermed er global opvarmning nu også sat på begreb i museernes strategiplan.

Som nævnt skal den globale vision i alle henseender anerkende diversitet og de former for uligheder, der ligger i forskellige kulturbegreber og livsformer. Den globale vision skal samtidig gøre adkomsten til netværket - elektronisk eller rent fysisk ved at deltage i møder - mere ens for alle. Kommunikation i netværket skal udvikles på alle måder. Det skal analy- sere, hvilke væsentlige barrierer, her er. I en workshop, som blev afholdt på konferencen omkring den strategiske plan, blev det diskuteret, hvorvidt der skal helt nye mødeformer til for at gøre det meningsfuldt men også økonomisk overkommeligt for flere medlemmer udenfor den vesteuropæiske verden at deltage. Det er diskussioner, som vi kan regne med fortsætter ved møderne i Advisory komitéen, hvor repræsentanter for alle nationale og internationale komiteer mødes en gang årligt. Tilbage til strategiplanen: Den elektroniske kommunikation skal tages ind og anvendes optimalt. På flere niveauer understreges det, at ICOM og museerne, som allerede har taget den moderne IT-teknologi til sig, skal udnytte den bedre og gøre den til en del af museerne professionelle værktøj og formidlingsmedie. Internt i ICOM skal man udvikle bedre metoder til at kommunikere over grænser og udvide de elektroniske platforme, så de bliver tilgængelige for flest mulige i netværket. Samtidig skal man være opmærksomme på regioner og områder, hvor elektronisk kommunikation ikke er anvendelig på samme niveau som i den dominerende del af verden, og gøre noget ved det. Eksternt skal man kommunikere med offentligheden via IT.

Hovedpunkterne i den strategiske plan om kulturel mangfoldighed, global gennemslags$\mathrm{kraft}$ og udvikling af de etiske regler gør det imidlertid stadig vigtigt, at ICOM fastholder sin grundidé med videreudvikling af museerne ved stadig at højne den professionelle standard. Og museumsetikken.

I arbejdet med museumsstandarder og professionel kunnen skal der dog således lægges stadig mere vægt på, at museerne også arbejder med immateriel kulturarv, folkekultur og livsformer, med indsamling og bevaring af uhåndgribelig kulturarv. 
86 Definitionen af museumsarbejde i samfundets tjeneste, som altid har ligget til grund for ICOM, er nu udbygget derved, at de samfundsmæssige implikationer af museumsarbejdet fremhæves ved at se naturen som kultur og udpege det sociale såvel som det kulturelle museernes virkefelter.

Med den strategiske plan er vi på vej til at kunne se helheden af delelementer. Og på vej til at øge fagligheden omkring immateriel indsamling og på at arbejde i spændingsfeltet mellem naturen, det social og det kulturelle, som i den vesteuropæiske kultur er spaltet ud i hver sine sektorer - men som mange andre steder i verden kun kan forstås som enhed af menneskers vilkår, det menneskeligt skabende og historien.

Metodeudviklingen omkring det immaterielle bliver en stor udfordring. Det var hovedtemaet på generalkonferencen i 2004. Og det er nu sat ind i den strategiske plan. Hvis komitéarbejdet, såvel i de nationale som de internationale komiteer, får greb om principperne for diversitet og metodeudvikler indsamling, udforskning og formidling af den immaterielle kulturarv i tværfaglige miljøer kan generalkonferencen 2010 blive rigtig spændende!

\section{*Merete Ipsen}

Museumsinspektor, Kvindemuseet,

Domkirkeplads 5

8000 Arhus $C$.

Tlf:: 86186470

Fax: 861922 35, 8000 Arhus $C$.

Email:mi@womensmuseum.dk.

Hjemmeside: http://www.kvindemuseet.dk/. 